\title{
IMPULSIVITY-COMPULSIVITY AXIS IN THE ABUSE OF INFORMATION AND COMMUNICATION TECHNOLOGIES (ICT) FROM THE PERSPECTIVE OF THE RESEARCH DOMAIN CRITERIA PROJECT (RDOC)
}

\author{
Eduardo J. Pedrero-Pérez', Sara Morales-Alonso', Vanessa Gallardo- \\ Arriero ${ }^{1}$, Laura Blázquez-Rollón ${ }^{1}$ and \\ José María Ruiz-Sánchez de León ${ }^{2}$

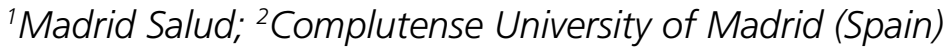

\begin{abstract}
The habit formation model to explain addiction involves the transition from an initial phase in which the prefrontal cortex ceases to control the behavior, to a phase in which control is transferred to the dorsal striatum, progressing towards compulsive consumption. This model, widely supported by empirical evidence, implies that each subject is at a certain point in the impulsivity-compulsivity continuum. Using two questionnaires recommended within the framework of the Research Domain Criteria Project which measure impulsivity and compulsivity, an attempt was made to confirm the existence of such a bipolar axis, applied to the abuse of information and communication technologies (ICT). The results of this study provide empirical support for the existence of this axis. The abuse of ICT seems to have many more compulsive components than impulsive ones, except in the case of video games, which are little related to both concepts. These results have important clinical implications, since there are very different therapeutic approaches for impulsivity and compulsive behavior.

KEY WORDS: impulsivity, compulsivity, addiction, information and communication technologies, population-based studies.
\end{abstract}

\begin{abstract}
Resumen
El modelo de formación de hábitos de la adicción implica la transición desde una fase inicial en la que la corteza prefrontal deja de controlar el comportamiento, a una fase en la que el control se transfiere al estriado dorsal, pasando al consumo compulsivo. Este modelo ampliamente apoyado por la evidencia empírica, implica que cada sujeto se encuentra en un determinado punto del continuo de impulsividad-compulsividad. Mediante dos cuestionarios recomendados en el marco del Proyecto de criterios de dominio de investigación (RDoC), que miden la impulsividad y la compulsividad, se intentó ratificar la existencia de ese eje bipolar, aplicado al abuso de las tecnologías de la información y las comunicaciones (TIC). Los resultados de este estudio encuentran apoyo empírico para la existencia de este
\end{abstract}

Correspondence: Eduardo J. Pedrero Pérez, Evaluation and Quality Department, Madrid Salud, Madrid City Council, Avda. del Mediterráneo, 6228007 Madrid (Spain). E-mail: pedreropej@madrid.es 
eje. El abuso de las TIC parece tener muchos más componentes compulsivos que impulsivos, excepto en el caso de los videojuegos, poco relacionados con ambos conceptos. Estos resultados tienen importantes implicaciones clínicas, en la medida en que existen enfoques terapéuticos muy diferentes para la impulsividad que para la conducta compulsiva.

PALABRAS CLAVE: impulsividad, compulsividad, adicción, tecnologías de la información y la comunicación, estudios poblacionales.

\section{Introduction}

Habit formation model of addiction involves the transition from an initial phase in which the prefrontal cortex ceases to control behaviour, to a phase in which drug addiction has been proposed to be explained as a transition from voluntary, recreational drug use to the formation and establishment of compulsive drugseeking habits, which neuronally translates into a transition from prefrontal cortical to striatal control over drug seeking and taking, as well as a progression of control from the ventral striatum to the dorsal striatum (Everitt, \& Robbins, 2016). In behavioural terms, substance use is related, at first, to the calculated search for positive reinforcement. Subsequently, and progressively, control of this behavior is lost, which manifests itself in episodes of abuse and subsequent bad consequences to, with repetition, become a compulsive search for negative reinforcement (George, 2019; Hyman, Malenka, \& Nestler, 2006).

According to this model, each person who develops an addictive process should be somewhere along the supposed impulsivity-compulsivity continuum, depending on the moment of transition between controlled behavior (prefrontal cortex) and compulsive habit (automated behavior controlled by the dorsal striatum). Only one study has been found that addresses the positioning of individuals on this continuum, using self-reports and neuropsychological performance tests, finding evidence in favour of the hypothesis (Fernández-Serrano et al., 2012). The existence of this continuum and the possibility of placing each subject at a certain point has important clinical implications. The treatment required by people whose behavior is guided by impulsivity, such as emission of behaviours guided by pleasure seeking and deficits in inhibition of responses without calculation of consequences, should not be the same as that received by those who act compulsively, seeking reduction of discomfort and with many more emotional components (Grant, \& Kim, 2014; Tiego et al., 2019).

The Research Domain Criteria Project (RDoC; Insel et al., 2010) has been proposed as a research framework for new ways of studying mental disorders, integrating many levels of information (from genomics to self-report) to better understand the basic dimensions of functioning that underlie the whole range of human behaviours, from normal to abnormal. Faced with the mere accumulation of symptoms used by the Diagnostic and statistical manual of mental disorders $\left(5^{\text {th }}\right.$ ed.) (DSM-5; American Psychiatric Association, 2013), the RDoC Project is designed to discover the neurological and neuropsychological bases of mental disorders. A broad group of experts from many nations have agreed that impulsivity and compulsivity are key constructs to understand addictive processes and have proposed suitable 
instruments for their measurement (Yücel et al., 2019). Among the self-report instruments proposed are the UPPS-P (Lynam et al., 2007) for impulsivity and OCDUS (Franken, Hendriks, \& van den Brink, 2002) for compulsivity.

There is currently an intense debate about the correct conceptualization of the so-called "behavioral addictions". Some authors defend its similarity to the wellknown substance addictions (e.g., Grant, Potenza, Weinstein, \& Gorelick, 2010; Robbins, \& Clark, 2015), while others consider it to be excessive, abusive or uncontrolled behaviours, but that are far from similar in many respects (Billieux, Schimmentic, Khazaal, Mauragea, \& Heerena, 2015; Panova, \& Carbonell, 2018). However, the neurological substrates of one and the other are very similar, involving a loss of higher control in favour of striatal control and the establishment of compulsive habits (Brand et al., 2019).

Impulsivity and compulsivity are not mutually exclusive; they share a large number of neural circuits and can manifest themselves together, although a clear predominance of one of them is generally identified Grant, \& Kim, 2014). The aim of the present study is to explore the possible existence of an impulsivitycompulsivity axis in Information and Communication Technology (ICT) abuse, using two questionnaires proposed in the RDoC Project and two complementary tests.

\section{Method}

\section{Participants}

An initial sample of $n=812$ subjects was obtained. After performing and outlier's analysis, 5 subjects were excluded $(0.6 \%)$, resulting in a final simple of $n=$ 807 subjects. Table 1 shows the descriptive data of the final sample.

\section{Instruments}

a) UPPS-P Impulsive Behavior Scale (UPPS-P; Lynam et al., 2007), adapted to Spanish by Cándido et al. (2012). The UPPS-P is a reduced version of 20 items, which measures five traits of impulsivity (4 items each): Negative urgency, Lack of premeditation, Lack of perseverance, Sensation seeking, and Positive urgency. Items are answered on a four-point Likert-type scale, from 1 ("strongly agree") to 4 ("strongly disagree"). The score is inverted on the two scales of Urgency and Sensation seeking so that all of them can be corrected in the direction of impulsivity; each one scoring between 4 and 16 . The internal consistency of the 5 scales, which was estimated by using Cronbach's $\alpha$, ranged from .61 to .81 , with the two Emergency scales below 0.70 , which is considered to be the lower admissible limit. In a more recent study in which this questionnaire was applied on the use/abuse of ICT, estimators of internal consistency were applied on the Likert-type scales and acceptable values for all subscales were found $(.75<\omega<.89)$ (Pedrero-Pérez et al., 2020). 
Table 1

Sociodemographic characteristics of the sample

\begin{tabular}{|c|c|c|c|}
\hline Sociodemographic variables & $\operatorname{Men}(n=261)$ & Women $(n=546)$ & Total $(n=807)$ \\
\hline \multicolumn{4}{|l|}{ Age (years) } \\
\hline $16-17$ & 4 & 9 & 13 \\
\hline $18-25$ & 32 & 96 & 128 \\
\hline $26-30$ & 38 & 69 & 107 \\
\hline $31-45$ & 72 & 141 & 213 \\
\hline $46-60$ & 88 & 173 & 261 \\
\hline$>60$ & 27 & 58 & 85 \\
\hline \multicolumn{4}{|l|}{ Educational level } \\
\hline Primary or less & 11 & 14 & 25 \\
\hline $\begin{array}{l}\text { Compulsory secondary } \\
\text { education }\end{array}$ & 16 & 14 & 30 \\
\hline Post-compulsory secondary & 56 & 63 & 119 \\
\hline University student & 19 & 60 & 79 \\
\hline University graduate & 159 & 395 & 554 \\
\hline \multicolumn{4}{|l|}{ Country of birth } \\
\hline Spain & 248 & 508 & 756 \\
\hline Central and South America & 11 & 32 & 43 \\
\hline Western Europe & 1 & 2 & 3 \\
\hline Eastern Europe & 1 & 2 & 3 \\
\hline Asia & - & 1 & 1 \\
\hline Africa & - & 1 & 1 \\
\hline \multicolumn{4}{|l|}{ Home country } \\
\hline Spain & 250 & 527 & 777 \\
\hline Central and South America & 7 & 13 & 20 \\
\hline North America & - & 1 & 1 \\
\hline Western Europe & 4 & 3 & 7 \\
\hline Eastern Europe & - & 1 & 1 \\
\hline Oceania & - & 1 & 1 \\
\hline
\end{tabular}

b) Obsessive-Compulsive Drug Use Scale for Information and Communication Technologies (OCDUS-ICT; Pedrero-Pérez, Morales-Alonso, \& Ruiz-Sánchez de León, 2021). The OCDUS-ICT is a 12-item self-report questionnaire. The OCDUS-ICT is based on the OCDUS, whose validation study (Franken, Hendriks, $\&$ van den Brink, 2002) found three factors: thoughts and interference (6 items), Desire and Control (4 items), and Resistance to thoughts and intention ( 2 items). It is answered on a 7-point analogic scale ( $1=$ none; $7=$ all the time). Items 6 and 12 must be reversed so that they all score towards compulsivity. Studies with previous versions showed adequate evidence of internal consistency and (e.g., Lievaart et al., 2015; Machielsen et al., 2012; Machielsen, Veltman, van den Brink, \& de Haan, 2018). The validation study of the OCDUS-ICT version ratified the three-factor structure by confirmatory factor analysis, as well as the internal consistency of the derived scales $(.71<\alpha<.84)$, using different estimators (Pedrero-Pérez, Morales-Alonso, \& Ruiz-Sánchez de León, 2021). 
c) MULTICAGE-ICT (Pedrero-Pérez et al., 2018). It is a 20-item questionnaire consisting of five scales designed to investigate problems related to the use of the Internet, cell phone, videogames, instant messaging, and social networks. It is based on MULTICAGE CAD-4, a compulsive behavior screening questionnaire, related and non-related to substances (Pedrero-Pérez et al., 2007), which has been used in primary care (Garrido-Elustondo, Reneses, Navalón, Martín, Ramos, \& Fuentes, 2016; Reneses et al., 2015; Rodríguez-Monje, Pedrero-Pérez, Fernández-Girón, Gallardo-Alonso, \& Sanz-Cuesta, 2009), behavioral addictions (Estevez, Herrero-Fernández, Sarabia, \& Jauregui, 2015; Estévez Gutiérrez, Herrero Fernández, Sarabia Gonzalvo, \& Jáuregui Bilbao, 2014; Megías et al., 2018) and substance addiction (Martínez-González, Munera-Ramos, \& BecoñaIglesias, 2013; Navas, Torres, Cándido, \& Perales, 2014; Navas, Verdejo-García, Lopez-Gomez, Maldonado, \& Perales, 2016; Pedrero-Pérez, 2010). A cell pone use/abuse scale was subsequently included (Rodríguez-Monje et al., 2019). The MULTICAGE-ICT asks four questions with a dichotomous answer (yes/no) for each beahvior problema, focusing on: item 1, self-estimated dedication time excess; item 2, estimated dedication time excess by significant others; item 3, difficulty in not performing the behavior; and item 4, difficulties in voluntarily interrupting the behavior. The psychometric study (Pedrero-Pérez et al., 2018) yielded adequate internal consistency of all its scales $(.74<\omega<.93)$ and evidence of structural validity

d) Short Prefrontal Symptom Inventory (PSI-20; Pedrero-Pérez, Ruiz-Sánchez de León, Morales-Alonso, Pedrero-Aguilar, \& Fernández-Méndez, 2015). The PSI20 explores symptoms of malfunction in daily life related to neuropsychological disorders attributable to the prefrontal cortex, is a 20-item scale with a 5-point Likert-type response format $(0=$ "never or hardly ever"; $1=$ "A few times"; $2=$ "Sometimes yes and sometimes no"; $3=$ "Many times"; $4=$ "Always or nearly always"). All items are formulated in the direction of the existence of symptoms of prefrontal malfunctioning, and the scores obtained in each subscale and in the complete scale should be added together. Factorial analysis revealed a threefactor solution: problems in behavioral control, problems in emotional control and problems in social behavior. Adequate internal consistency of all the subscales was reported both in the general population and in addicts under treatment $(.87<\alpha<.89)$, as well as in clinical validity tests (Ruiz-Sánchez de León, Pedrero-Pérez, Gálvez, Fernández-Méndez, \& Lozoya-Delgado, 2015), ecological validity (Pedrero-Pérez et al., 2016) and cross-cultural validity (González Roscigno, Mujica Díaz, Terán Mendoza, Guerrero Alcedo, \& Arroyo Alvarado, 2016; Mendoza, Cuello, \& López, 2016). In the study simple of the present work, the multivariate consistency $\left(\alpha_{s}\right)$ was .90 for the total score and between .81 and .90 for the scales.

\section{Procedure}

Since the target population was regular ICT users, a survey was carried out using Google Docs and anonymous and voluntary participation was requested through instant messaging programs (WhatsApp), social networks (Facebook, 
Instagram) and e-mail. At the same time, dissemination to the participants' contacts was requested, using a chain sampling technique. In the presentation, participants were informed of the objective of the study and all of them checked the box in which it was declared that "I wish to participate voluntarily". The procedure guaranteed anonymity and the impossibility of associating each participant with their responses. Data collection started on January 2 and stopped on April 3, 2019.

First, the existence of atypical scores (outliers) was studied using the Mahalanobis distance, applying the criterion of $p<.001$ for exclusion. Next, to ensure the adequacy of the questionnaires, the internal consistency of the tests and their subscales was studied using the McDonald ordinal omega test $(\omega)$. The scores of all the tests were recoded into a distribution between 0 (lowest possible score) and 100 (highest possible score), according to the formula:

$$
x_{100}=(x-m p p) * 100 / M P P-m p p
$$

where $\mathrm{x}=$ test score; $\mathrm{mp} \mathrm{p}=$ lowest possible score; $\mathrm{MPP}=$ highest possible score; $\mathrm{x}_{100}=$ score on a scale of 0 to 100 . Next, the scores obtained by men and women were compared by means of an analysis of covariance, controlling the variables that showed an interaction effect, using Wilks' lambda $(\lambda)$. To estimate the effect size of the observed differences, the omega squared $\left(\omega^{2}\right)$ was applied, whose values are interpreted as: 0.01 small effect size, 0.06 medium size and 0.14 large (Cohen, 2008). Subsequently, a multivariate linear regression analysis of all variables was performed on the MULTICAGE-ICT scales, using beta $(\beta)$ as the effect size estimator, which is interpreted as weak effect size when it is less than 0.20 , moderate between .20 and .50 and high when it is greater than.50 (Acock, 2014). Finally, a scaling procedure of the combined Impulsivity and Compulsivity scores was applied, through the following steps: first, a mean Impulsivity score was obtained (by summing the typed scores of the five UPPS-P scales and dividing by 5) and a mean Compulsivity score (by summing the typed scores of the three OCDUS-ICT scales and dividing by 3 ). The scores obtained were again typed into a distribution of mean 50 and standard deviation 10. The Compulsivity score was subtracted from the Impulsivity score, obtaining a new distribution in which higher scores would correspond to a predominance of Impulsivity, while the lower ones would indicate a predominance of Compulsivity. Finally, the subjects were grouped into the following categories: High Impulsivity, Moderate Impulsivity, Equilibrium, Moderate Compulsivity and High Compulsivity. Once the subjects were classified, the mean scores obtained in all the questionnaires were studied to check if the scores of each group showed relevant differences. The SPSS 22 statistical package and the FACTOR 10.10.01 program was used for all analyses.

\section{Results}

Internal consistency of tests

In previous studies, the structural validity of these data was verified in a sample similar to that used in the present study (the responses of several dozen participants who responded later have been added). In both cases a confirmatory factor analysis was performed, which reported the excellent fit of the theoretical propositions to 
the data obtained (Pedrero-Pérez et al., 2020, 2021). Table 2 shows the internal consistency values obtained by scales and subscales applied.

\section{Table 2}

Internal consistency of the applied questionnaires and their subscales

\begin{tabular}{|l|c|l|c|}
\hline \multicolumn{1}{|c|}{ Questionnaires/Subscales } & $\omega$ & Questionnaires/Subscales & $\omega$ \\
\hline MULTICAGE & .89 & UPPS-P & .88 \\
\hline Internet & .81 & Lack of perseverance & .86 \\
\hline Cell phone & .71 & Lack of premeditation & .82 \\
\hline Videogames & .87 & Sensation seeking & .86 \\
\hline Instant messaging & .86 & Negative urgency & .89 \\
\hline Social networks & .93 & Positive urgency & .75 \\
\hline PSI-20 & .91 & OCDUS-ICT & .92 \\
\hline Emotional control & .82 & Thought-Interference & .87 \\
\hline Executive control & .89 & Desire-Control & .86 \\
\hline Social behavior control & .87 & Resistance & .81 \\
\hline Total prefrontal symptoms & .91 & & \\
\hline
\end{tabular}

\section{Gender differences}

Next, differences by gender were estimated for each of the dimensions measured by the instruments used. Both gender $\left(\lambda_{16,788}=.76 ; p<.001\right)$ and age $\left(\lambda_{16}\right.$, $788=.71 ; p<.001)$ and educational level $\left(\lambda_{16,788}=.92 ; p<.001\right)$ showed interaction effect. Therefore, differences by gender were calculated controlling for age and educational level. Table 3 shows that statistical significance appears for almost all the differences, although the effect size of these differences is low or moderate, except in three cases where it is considerably high: men score higher on Internet abuse and Sensation seeking, and women score higher on Social network abuse.

\section{Regression analysis}

A linear regression analysis of the sociodemographic variables and the rest of the instruments was performed on each of the ICT use/abuse scales. Table 4 shows that the variable with the greatest explanatory capacity of all the ICT use/abuse scales was the Desire/Control variable of the instrument that measures compulsiveness. This scale measures the frequency and intensity of the desire to connect and the inability to resist the urge to do so. The effect size is moderate in almost all cases, except for video games, which is low, and mobile, where it reaches a high effect size. The rest of the scales contribute much smaller proportions to the model and in almost all cases with a low effect size. 
Table 3

Difference by gender in the scores obtained in the tests administered, controlling for age and educational level

\begin{tabular}{|l|c|c|c|c|c|c|}
\hline \multirow{2}{*}{ Questionnaire/Subscale } & \multicolumn{2}{|c|}{ Men } & \multicolumn{2}{c|}{ Women } & & \\
\cline { 2 - 7 } & $M$ & $S D$ & $M$ & $S D$ & $F_{3}$ & $\omega^{2}$ \\
\hline MULTICAGE & & & & & & \\
\hline Internet & 34.67 & 30.46 & 33.93 & 30.69 & $39.7^{*}$ & .13 \\
\hline Cell phone & 39.85 & 25.80 & 44.23 & 28.07 & $17.4^{*}$ & .06 \\
\hline Videogames & 11.88 & 21.32 & 8.42 & 19.39 & $13.5^{*}$ & .05 \\
\hline Instant messaging & 25.29 & 29.05 & 35.99 & 32.60 & $30.0^{*}$ & .10 \\
\hline Social networks & 14.08 & 25.01 & 21.25 & 31.54 & $48.9^{*}$ & .16 \\
\hline PSI-20 & & & & & & \\
\hline Emotional control & 23.01 & 17.25 & 30.44 & 20.28 & $21.3^{*}$ & .07 \\
\hline Executive control & 24.96 & 14.41 & 21.79 & 13.64 & $17.1^{*}$ & .06 \\
\hline Social behavior control & 16.55 & 15.69 & 10.00 & 12.79 & $17.6^{*}$ & .06 \\
\hline Total prefrontal symptoms & 23.51 & 12.59 & 21.71 & 12.25 & $18.3^{*}$ & .06 \\
\hline UPPS-P & & & & & & \\
\hline Lack of perseverance & 22.70 & 17.16 & 19.63 & 16.60 & $6.7^{*}$ & .02 \\
\hline Lack of premeditation & 24.27 & 17.24 & 24.57 & 15.98 & 2.7 & .01 \\
\hline Sensation seeking & 49.07 & 20.01 & 40.58 & 18.81 & $53.5^{*}$ & .17 \\
\hline Negative urgency & 47.54 & 19.28 & 47.34 & 18.11 & $7.9^{*}$ & .03 \\
\hline Positive urgency & 47.22 & 16.83 & 45.38 & 14.44 & $17.4^{*}$ & .06 \\
\hline OCDUS-ICT & & & & & & \\
\hline Thought-Interference & 24.63 & 16.41 & 21.34 & 15.24 & $26.7^{*}$ & .09 \\
\hline Desire-Control & 30.32 & 19.45 & 31.46 & 19.98 & $22.9^{*}$ & .08 \\
\hline Resistance & 17.24 & 17.42 & 17.23 & 19.79 & $37.0^{*}$ & .12 \\
\hline
\end{tabular}

Note: $\omega^{2}=$ Omega squared; $\left(^{*}\right)$ Significant for $p<.001$.

\section{Establishment of an impulsivity-compulsivity axis}

When the compulsivity score was subtracted from the impulsivity score, a new distribution was obtained with $M=0.0$ and $S D=11.3$, and a range between 38.0 and -41.3 , in which higher scores would correspond to a predominance of impulsivity, while lower scores would indicate a predominance of compulsivity. Finally, subjects were grouped into the following categories: high impulsivity ( $>20$; $n=28$ ), moderate impulsivity (between 10.01 and 20; $n=111$ ), equilibrium (between 10 and $-10 ; n=517)$, moderate compulsivity (-9.99 and $-20 ; n=119)$ and high compulsivity $(<-20 ; n=32)$. Table 5 shows the centralization and dispersion values of the variables according to the assigned group and a number of issues can be observed:

a. That impulsivity scores decline gradually in all categories, being highest in the High Impulsivity group and lowest in the High Compulsivity group.

b. That the compulsivity scores behave inversely, being maximal in the High Compulsivity group and minimal in the High Impulsivity group.

c. That the maximum scores of Prefrontal Symptoms correspond to the High Impulsivity pole. 
d. That ICT abuse scores correspond to the High Compulsivity pole, except in the case of video games.

Table 4

Linear regression of the sociodemographic variables and the rest of the questionnaires on the ICT use/abuse scales of the MULTICAGE-ICT

\begin{tabular}{|c|c|c|c|c|c|}
\hline \multirow{3}{*}{ Model } & \multicolumn{5}{|c|}{ MULTICAGE } \\
\hline & \multicolumn{5}{|c|}{$R^{2} \times 100$ or $\%$ of variance explained $(\beta)$} \\
\hline & Internet & Cell phone & Videogames & $\begin{array}{c}\text { Instant } \\
\text { messaging }\end{array}$ & $\begin{array}{c}\text { Social } \\
\text { networks }\end{array}$ \\
\hline Gender & & $\begin{array}{l}0.3 \% \\
(0.06)\end{array}$ & & $\begin{array}{l}2.0 \% \\
(0.16)\end{array}$ & $\begin{array}{l}1.2 \% \\
(0.13) \\
\end{array}$ \\
\hline Age & $\begin{array}{c}4.1 \% \\
(-0.19) \\
\end{array}$ & $\begin{array}{c}0.5 \% \\
(-0.06) \\
\end{array}$ & $\begin{array}{c}0.6 \% \\
(-0.09) \\
\end{array}$ & $\begin{array}{c}0.9 \% \\
(-0.10) \\
\end{array}$ & $\begin{array}{l}6.7 \% \\
(-0.22) \\
\end{array}$ \\
\hline Educational level & & & $\begin{array}{l}1.9 \% \\
(-0.12)\end{array}$ & $\begin{array}{l}0.3 \% \\
(0.06)\end{array}$ & \\
\hline \multicolumn{6}{|l|}{ PSI-20 } \\
\hline \multicolumn{6}{|l|}{$\begin{array}{l}\text { Emotional } \\
\text { control }\end{array}$} \\
\hline Executive control & & & & & $\begin{array}{l}0.7 \% \\
(0.09)\end{array}$ \\
\hline $\begin{array}{l}\text { Social behavior } \\
\text { control }\end{array}$ & & & & $\begin{array}{l}0.4 \% \\
(0.07)\end{array}$ & \\
\hline $\begin{array}{l}\text { Total prefrontal } \\
\text { symptoms }\end{array}$ & & & $\begin{array}{l}1.4 \% \\
(0.12) \\
\end{array}$ & & \\
\hline \multicolumn{6}{|l|}{ UPPS-P } \\
\hline \multicolumn{6}{|l|}{$\begin{array}{l}\text { Lack of } \\
\text { perseverance }\end{array}$} \\
\hline $\begin{array}{l}\text { Lack of } \\
\text { premeditation }\end{array}$ & & $\begin{array}{c}0.4 \% \\
(-0.06)\end{array}$ & & & \\
\hline $\begin{array}{l}\text { Sensation } \\
\text { seeking }\end{array}$ & & & & & $\begin{array}{l}0.4 \% \\
(0.07)\end{array}$ \\
\hline \multicolumn{6}{|l|}{$\begin{array}{l}\text { Negative } \\
\text { urgency }\end{array}$} \\
\hline \multicolumn{6}{|l|}{ Positive urgency } \\
\hline \multicolumn{6}{|l|}{ OCDUS-ICT } \\
\hline $\begin{array}{l}\text { Thought- } \\
\text { Interference }\end{array}$ & $\begin{array}{l}2.1 \% \\
(0.20)\end{array}$ & & & $\begin{array}{l}0.3 \% \\
(0.10)\end{array}$ & $\begin{array}{l}0.9 \% \\
(0.14)\end{array}$ \\
\hline Desire-Control & $\begin{array}{c}34.3 \% \\
(0.39)\end{array}$ & $\begin{array}{l}34.0 \% \\
(0.51)\end{array}$ & $\begin{array}{l}4.2 \% \\
(0.15)\end{array}$ & $\begin{array}{l}26.7 \% \\
(0.34)\end{array}$ & $\begin{array}{l}22.0 \% \\
(0.27)\end{array}$ \\
\hline Resistance & $\begin{array}{l}0.5 \% \\
(0.07)\end{array}$ & $\begin{array}{l}0.2 \% \\
(0.07) \\
\end{array}$ & & $\begin{array}{l}1.7 \% \\
(0.11) \\
\end{array}$ & \\
\hline $\begin{array}{l}\text { Total variance } \\
\text { explained by the } \\
\text { joint model }\end{array}$ & $41.0 \%$ & $35.4 \%$ & $8.1 \%$ & $32.3 \%$ & $31.9 \%$ \\
\hline
\end{tabular}

In the distribution of the sample by gender in the different groups, no significant differences appeared $\left(\chi^{2}{ }_{4}=7.7, p=0.10, V=0.10\right)$. 
Table 5

Mean scores and standard deviations (in italics and between brackets) of the different scales according to the impulsivity-compulsivity axis groups

\begin{tabular}{|c|c|c|c|c|c|c|}
\hline Scales/subscales & & $\begin{array}{l}\text { Alta } \\
\text { IMP }\end{array}$ & $\begin{array}{l}\text { Moderada } \\
\text { IMP }\end{array}$ & Equilibrio & $\begin{array}{l}\text { Moderada } \\
\text { COMP }\end{array}$ & $\begin{array}{l}\text { Alta } \\
\text { COMP }\end{array}$ \\
\hline \multicolumn{7}{|l|}{ Gender } \\
\hline Men & $\%$ & 4.6 & 17.2 & 62.8 & 12.6 & 2.7 \\
\hline Women & $\%$ & 2.9 & 12.1 & 64.7 & 15.8 & 4.6 \\
\hline \multicolumn{7}{|l|}{ UPPS-P } \\
\hline \multirow{2}{*}{ Lack of perseverance } & $M$ & 35.42 & 31.53 & 19.70 & 14.01 & 9.37 \\
\hline & $S D$ & $(18.51)$ & $(15.79)$ & $(15.91)$ & $(15.30)$ & $(11.93)$ \\
\hline \multirow{2}{*}{ Lack of premeditation } & $M$ & 41.37 & 34.16 & 24.02 & 15.41) & 17.19 \\
\hline & $S D$ & $(17.34)$ & $(14.91)$ & $(15.87)$ & $(12.87)$ & $(11.96)$ \\
\hline \multirow{2}{*}{ Sensation seeking } & $M$ & 61.01 & 53.15 & 42.49 & 35.01 & 38.28 \\
\hline & $S D$ & $(23.36)$ & $(19.14)$ & $(18.63)$ & $(17.41)$ & $(18.68)$ \\
\hline \multirow{2}{*}{ Negative urgency } & $M$ & 69.94 & 57.21 & 46.08 & 41.18 & 38.28 \\
\hline & $S D$ & $(18.19)$ & $(17.89)$ & $(17.77)$ & $(15.77)$ & $(13.86)$ \\
\hline \multirow{2}{*}{ Positive urgency } & $M$ & 68.15 & 54.13 & 44.54 & 40.69 & 41.15 \\
\hline & $S D$ & $(15.22)$ & $(16.16)$ & $(13.74)$ & $(14.52)$ & $(11.77)$ \\
\hline \multicolumn{7}{|l|}{ OCDUS-ICT } \\
\hline \multirow{2}{*}{ Thoughts/Interference } & $M$ & 12.20 & 15.09 & 21.14 & 30.72 & 46.18 \\
\hline & $S D$ & $(9.33)$ & $(12.02)$ & $(14.40)$ & $(15.34)$ & $(17.51)$ \\
\hline \multirow{2}{*}{ Desire/Control } & $M$ & 17.11 & 20.35 & 29.64 & 42.30 & 62.37 \\
\hline & $S D$ & $(15.85)$ & $(16.80)$ & $(18.32)$ & $(16.89)$ & $(13.70)$ \\
\hline \multirow{2}{*}{ Resistance } & $M$ & 7.44 & 7.13 & 14.31 & 32.70 & 50.52 \\
\hline & $S D$ & (14.93) & (9.98) & $(15.26)$ & $(22.61)$ & $(20.18)$ \\
\hline \multicolumn{7}{|l|}{ PSI-20 } \\
\hline \multirow{2}{*}{ Emotional } & $M$ & 39.51 & 31.70 & 27.72 & 23.69 & 26.56 \\
\hline & $S D$ & $(20.35)$ & $(19.14)$ & $(19.52)$ & $(18.89)$ & $(20.82)$ \\
\hline \multirow{2}{*}{ Executive } & $M$ & 29.57 & 27.37 & 22.07 & 20.12 & 23.25 \\
\hline & $S D$ & $(12.24)$ & $(14.34)$ & $(14.05)$ & $(12.92)$ & $(11.68)$ \\
\hline \multirow{2}{*}{ Social } & $M$ & 23.88 & 17.34 & 11.44 & 8.93 & 6.64 \\
\hline & $S D$ & $(19.40)$ & $(16.01)$ & $(13.53)$ & $(11.95)$ & $(7.77)$ \\
\hline \multirow{2}{*}{ Prefrontal symptoms } & $M$ & 31.16 & 26.91 & 21.62 & 19.10 & 21.17 \\
\hline & $S D$ & $(11.21)$ & $(12.47)$ & $(12.32)$ & $(11.50)$ & $(9.93)$ \\
\hline \multicolumn{7}{|l|}{ MULTICAGE-ICT } \\
\hline \multirow{2}{*}{ Internet } & $M$ & 32.14 & 26.58 & 31.77 & 43.91 & 64.84 \\
\hline & $S D$ & $(31.81)$ & $(25.51)$ & $(29.61)$ & $(31.55)$ & $(33.52)$ \\
\hline \multirow{2}{*}{ Cell phone } & $M$ & 33.93 & 34.91 & 41.78 & 48.74 & 72.66 \\
\hline & $S D$ & $(23.78)$ & $(23.42)$ & $(27.45)$ & $(26.21)$ & $(24.06)$ \\
\hline \multirow{2}{*}{ Videogames } & $M$ & 11.61 & 9.01 & 8.80 & 13.66 & 6.25 \\
\hline & $S D$ & $(23.06)$ & $(19.30)$ & $(18.54)$ & $(25.58)$ & $(20.08)$ \\
\hline \multirow{2}{*}{ Instant messaging } & $M$ & 23.21 & 27.70 & 29.50 & 41.18 & 74.22 \\
\hline & $S D$ & $(27.16)$ & $(27.67)$ & $(30.70)$ & $(32.32)$ & $(31.42)$ \\
\hline \multirow{2}{*}{ Social networks } & $M$ & 26.79 & 13.51 & 16.34 & 24.79 & 50.78 \\
\hline & $S D$ & $(33.28)$ & $(23.78)$ & $(27.73)$ & $(33.43)$ & (39.39) \\
\hline
\end{tabular}


This study aims to explore the possible existence of an impulsivity-compulsivity axis in the abuse of information and communication technologies (ICT) similar to that previously proposed for people with cocaine addiction (Fernández-Serrano et al., 2012). The data suggest that it is indeed possible to place the subjects in our sample of the population of ICT users on an axis between impulsivity, as the beginning of the mismanagement of the prefrontal cortex to control behavior, and compulsivity, as a state in which the habit has been established and is executed to reduce the discomfort of not doing so. This is suggested by the fact that people with very high scores in impulsivity (UPPS-P) have very low scores in compulsivity (OCDUS$\mathrm{TIC}$ ) and are therefore grouped in the group called High Impulsivity. In the same way, people with very high scores in compulsivity (OCDUS-ICT) have very low scores in impulsivity (UPPS-P) and are grouped in the group called High Compulsivity (see Table 5). The transit between the two poles is represented by people in the intermediate groups, as hypothesized in the framework of the Everitt and Robbins (2016) model.

Along the same lines of explanation, it is interesting to note that the High Impulsivity group is the group that brings together people who report more prefrontal symptomatology (ISP-20) and, as one moves along the axis towards the High Compulsivity group, the scores are reduced. Trait impulsivity has been reconceptualized from the neuropsychological approach as deficits in behavioral inhibition (Leshem, \& Yefet, 2019) and is related to a failure in the functioning of the orbitofrontal cortex (Balasubramani, Pesce, \& Hayden, 2019). In contrast, compulsivity has been studied mainly associated with obsessive-compulsive disorder and, in animal studies, has been linked to a hyperfunctioning of the medial prefrontal cortex and its connection with the dorsal striatum (Manning, Dombrovski, Torregrossa, \& Ahmari, 2019) and specifically to compulsive alcohol consumption (Siciliano et al., 2019). Possibly this would explain why the High Impulsivity group obtains the highest scores in symptoms of daily malfunctioning of prefrontal origin, while the High Compulsivity group does not present such high values, predominantly those affecting emotional control. These values have already been found in previous studies with the same instruments (Pedrero-Pérez et al., 2020 a,b).

The data also point to the fact that ICT abuse is much more linked to compulsiveness than impulsivity, and this both when talking about environments (Internet), physical media (smartphone) and applications (instant messaging). and social networks). This would mean that when a person persists in the use of ICT, he does not do it out of a mere impulse without calculation of consequences, but, we could say, to reduce the discomfort that not doing so would cause them. However, the results point to an exception: the use of video games seems to be governed by very different rules. Indeed, involvement in video games requires, in most cases, intense participation, which observers can confuse with abuse, when it completely lacks pathological components (Billieux, Flayelle, Rumpf, \& Stein, 2019). On the other hand, continued involvement in these video games requires intense training, with a great investment of cognitive and motor resources oriented to well-defined goals and a commitment to improving performance to achieve them. The involvement in video games shows a solid relationship with intelligence scores 
(Quiroga et al., 2009) and structural changes in brain anatomy that reflect the specialization in the required tasks (Colom et al., 2012). In fact, they have been proposed both as measures of intellectual performance (Quiroga, Román, de la Fuente, Privado, \& Colom, 2016), as useful strategies for cognitive rehabilitation (Quiroga et al., 2009). These characteristics widely differentiate them from the rest of the ICT explored, as has already been found in previous studies (Pedrero-Pérez et al., 2018) and possibly justify their scoring low both in the impulsivity and compulsiveness pole.

Before establishing the bipolar impulsivity-compulsiveness axis, some psychometric characteristics of the tests used were studied. All the scales used and their corresponding subscales have shown satisfactory internal consistency, a prerequisite for the interpretation of the results. The previous regression analysis also indicates that it is the compulsive components that most explain the abuse of ICT, especially the Desire-control scale, which reflects the unstable balance between the desire to perform the behavior and the control that the subject exercises to slowing down the execution until that control is overcome and the neutralizing behavior is triggered. This scale seems to represent the core of ICT abuse, except, again, in the case of video games, where it is still the most important element, but with a much smaller effect size.

There are also very significant differences according to the gender of the participants. While men score more in Internet abuse, women do so with a higher effect size in social networks. This has already been found in previous studies (Pedrero et al., 2018) and reflects a known fact: that men are more oriented to challenging tasks, probably also related to their higher score in Sensation Seeking, and women more to activities that involve social contact. The causes of these differences are not clear, which appear systematically in almost all studies, and which may be due to biological, educational or socially assigned role differences (Jäncke, 2018).

Age is related to the abuse of ICTs, as has been shown on previous occasions, although, combined with the rest of the variables, its explanatory power is small. In all ICTs, age is a negative predictor of abuse, which means that as time passes, the chances of establishing problem behavior decrease. It only predicts a significant proportion of the variance of abuse in the case of social networks and the Internet, with a moderate effect size. Therefore, it can be deduced that the relationships between problematic use of ICT and the impulsivity and compulsivity variables will remain stable in the different age groups.

The present study has limitations. First, the recruitment method does not guarantee the generalizability of the results. People have participated voluntarily, but nothing guarantees their sincerity. However, an outlier detection analysis has been carried out to exclude atypical scores, which has made it necessary to dispense with a minimum part of the sample $(0.6 \%)$. This fact and the internal consistency of all the tests administered can be considered indications of consistency in participation in the study. On the other hand, the procedure for obtaining the impulsivity-compulsiveness axis is tentative: simple in the steps carried out, but complex in its general formulation. Very likely, in the future, a standardized method 
may be available that allows each subject to be placed at some point on this continuum, which can be of great value in the clinic.

In conclusion, the data from the present study support the existence of a bipolar axis between impulsivity and compulsiveness, in which each subject can be situated at a specific point. This, on the one hand, confirms the neuropsychological model of addiction proposed by Everitt and Robbins (2016) also for the problematic use of ICT, something also obtained in similar work with machine learning analysis methods (Cassú-Ponsatí, Pedrero-Pérez, Morales-Alonso y Ruiz-Sánchez de León, 2021). This does not imply that ICT abuse should be considered addictive behavior, but it does mean that such abuse shares common neuropsychological substrates. On the other hand, it suggests a clinical application of enormous interest: the psychological and neuropsychological treatment of impulsivity is significantly different from that of compulsivity, and the existence of this axis may favour the matching of each subject with their more specific treatment. Currently, the treatment of addictions and similar behaviours does not take into account the evolutionary moment of the subject and its relationship with the substance or behavior, being applied in a standard way for all patients. This may be related to the high dropout rates presented by current treatments, which could be reduced if personality characteristics and cognitive functioning were assessed (Brorson, Arnevik, Rand-Hendriksen, \& Duckert, 2013), which would include location on the impulsivity-compulsiveness axis. Future studies should address the evaluation of position in this axis including neuropsychological performance tests that facilitate the characterization of each subject and prescribe the components of cognitive rehabilitation applicable in each case.

\section{References}

Acock, A. C. (2014). A gentle introduction to stata (4a ed.) College Station, TX: Stata Press.

American Psychiatric Association. (2013). Diagnostic and statistical manual of mental disorders ( $5^{\mathrm{a}}$ ed.). Arlington, VA: Autor.

Balasubramani, P. P., Pesce, M. C., \& Hayden, B. Y. (2020). Activity in orbitofrontal neuronal ensembles reflect inhibitory control. European Journal of Neuroscience, 51(10), 20332051.

Billieux, J., Flayelle, M., Rumpf, H. J., \& Stein, D. J. (2019). High involvement versus pathological involvement in video games: A crucial distinction for ensuring the validity and utility of gaming disorder. Current Addiction Reports, 6, 323-330.

Billieux, J., Schimmentic, A., Khazaal, Y., Mauragea, P., \& Heerena, A. (2015). Are we overpathologizing everyday life? A tenable blueprint for behavioral addiction research. Journal of Behavioral Addictions, 4, 119-123.

Brand, M., Wegmann, E., Stark, R., Müller, A., Wölfling, K., Robbins, T. W., \& Potenza, M. N. (2019). The interaction of person-affect-cognition-execution (I-PACE) model for addictive behaviors: Update, generalization to addictive behaviors beyond Internet-use disorders, and specification of the process character of addictive behaviors. Neuroscience \& Biobehavioral Reviews, 104, 1-10.

Brorson, H. H., Arnevik, E. A., Rand-Hendriksen, K., \& Duckert, F. (2013). Drop-out from addiction treatment: A systematic review of risk factors. Clinical Psychology Review, 33(8), 1010-1024. 
Cándido, A., Orduña, E., Perales, J. C., Verdejo-García, A., \& Billieux, J. (2012). Validation of a short Spanish version of the UPPS-P Impulsive Behaviour Scale. Trastornos Adictivos, 14, 73-78.

Cassú-Ponsatí, D., Pedrero-Pérez, E. J., Morales-Alonso, S., \& Ruiz-Sánchez de León, J. M. (2021). Impulsivity-compulsivity axis: Evidence of its clinical validity to individually classify subjects on the use/abuse of information and communication technologies. Frontiers in Psychology, 12, 647682.

Cohen, B. H. (2008). Explaining psychological statistics. Hoboken, NJ: John Wiley \& Sons.

Colom, R., Quiroga, M. Á., Solana, A. B., Burgaleta, M., Roman, F. J., Privado, J., Escorial, S., Martíneza, K., Álvarez-Linera, J., Alfayate, E., García F., Lepage, C., HernándezTamames, J. A., \& Karamady, S. (2012). Structural changes after videogame practice related to a brain network associated with intelligence. Intelligence, 40(5), 479-489.

Estevez, A., Herrero-Fernández, D., Sarabia, I., \& Jauregui, P. (2015). The impulsivity and sensation-seeking mediators of the psychological consequences of pathological gambling in adolescence. Journal of Gambling Studies, 31, 91-103.

Estévez Gutiérrez, A., Herrero Fernández, D., Sarabia Gonzalvo, I., \& Jáuregui Bilbao, P. (2014). El papel mediador de la regulación emocional entre el juego patológico, uso abusivo de Internet y videojuegos y la sintomatología disfuncional en jóvenes y adolescentes [Mediating role of emotional regulation between impulsive behavior in gambling, Internet and videogame abuse, and dysfunctional symptomatology in young adults and adolescents.]. Adicciones, 26, 282-290.

Everitt, B. J., \& Robbins, T. W. (2016) Drug addiction: Updating actions to habits to compulsions ten years on. Annual Review of Psychology, 67, 23-50.

Fernández-Serrano, M. J., Perales-López, J. C., Moreno-Lopez, L., Santos-Ruiz, A., PerezGarcia, M., \& Verdejo-García, A. (2012). Impulsividad y compulsividad en individuos dependientes de cocaína [Impulsivity and compulsivity in cocaine dependent individuals]. Adicciones, 24, 105-113.

Franken, I. H., Hendriks, V. M., \& van den Brink, W. (2002). Initial validation of two opiate craving questionnaires: The Obsessive Compulsive Drug Use Scale and the Desires for Drug Questionnaire. Addictive Behaviors, 27, 675-685.

Garrido-Elustondo, S., Reneses, B., Navalón, A., Martín, O., Ramos, I., \& Fuentes, M. (2016). Capacidad de detección de patología psiquiátrica por el médico de familia [Ability to detect psychiatric disorders by the family physician]. Atención Primaria, 48, 449-457.

George, O. (2019). Negative reinforcement mechanisms in addiction. In M. Torregrosa (Ed.), Neural mechanisms of addiction (pp. 179-188). Cambridge, MA: Academic Press.

González Roscigno, E. A., Mujica Díaz, A. L., Terán Mendoza, O. E., Guerrero Alcedo, J. M., \& Arroyo Alvarado, D. J. (2016). Sintomatología frontal y trastornos de personalidad en usuarios de drogas ilícitas [Frontal symptoms and personality disorders in illicit drug users]. Drugs and Addictive Behavior, 1, 17-28.

Grant, J. E., \& Kim, S. W. (2014). Brain circuitry of compulsivity and impulsivity. CNS Spectrums, 19, 21-27.

Grant, J. E., Potenza, M. N., Weinstein, A., \& Gorelick, D. A. (2010). Introduction to behavioral addictions. American Journal of Drug and Alcohol Abuse, 36, 233-241.

Hyman, S. E., Malenka, R. C., \& Nestler, E. J. (2006) Neural mechanisms of addiction: The role of reward-related learning and memory. Annual Review of Neuroscience, 29, 565-598.

Insel, T., Cuthbert, B., Garvey, M., Heinssen, R., Pine, D. S., Quinn, K., Sanislow, C., \& Wang, P. (2010). Research Domain Criteria (RDoC): Toward a new classification framework for research on mental disorders. American Journal of Psychiatry, 167, 748-751.

Jäncke, L. (2018). Sex/gender differences in cognition, neurophysiology, and neuroanatomy. F1000 Research, 805. doi: 10.12688/f1000research.13917.1 
Leshem, R., \& Yefet, M. (2019). Does impulsivity converge distinctively with inhibitory control? Disentangling the cold and hot aspects of inhibitory control. Personality and Individual Differences, 145, 44-51.

Lievaart, M., Erciyes, F., van der Veen, F. M., van de Wetering, B. J., Muris, P., \& Franken, I. $\mathrm{H}$. (2015). Validation of the cocaine versions of the Obsessive-Compulsive Drug Use Scale and the Desires for Drug Questionnaire. American Journal of Drug and Alcohol Abuse, 41, 358-365.

Lynam, D. R., Smith, G. T., Cyders, M. A., Fischer, S., \& Whiteside, S. P. (2007) The UPPS-P questionnaire measure of five dispositions to rash action [Unpublished technical report]. Purdue University, West Lafayette, IN.

Machielsen, M., Scheltema Beduin, A., Dekker, N., Kahn, R. S., Linszen, D. H., van Os. J., Wiersma, D., Bruggeman, R., Cahn, W., de Haan, L., Krabbendam, L., \& Myin-Germeys, I. (2012). Differences in craving for cannabis between schizophrenia patients using risperidone, olanzapine or clozapine. Journal of Psychopharmacology, 26, 189-195.

Machielsen, M. W., Veltman, D. J., van den Brink, W., \& de Haan, L. (2018). Comparing the effect of clozapine and risperidone on cue reactivity in male patients with schizophrenia and a cannabis use disorder: A randomized fMRI study. Schizophrenia Research, 194, 32-38.

Manning, E. E., Dombrovski, A. Y., Torregrossa, M. M., \& Ahmari, S. E. (2019). Impaired instrumental reversal learning is associated with increased medial prefrontal cortex activity in Sapap3 knockout mouse model of compulsive behavior. Neuropsychopharmacology, 44(8), 1494-1504.

Martínez-González, J. M., Munera-Ramos, P., \& Becoña-Iglesias, E. (2013). Drogodependientes vs. usuarios de salud mental con trastornos de personalidad: su relación con la calidad de vida, la psicopatología en Eje I, el ajuste psicológico y dinámica familiar [Addicts vs mental health users with personality disorders: its relation to quality of life in Axis I psychopathology, psychological adjustment and family dynamics]. Anales de Psicología, 29, 48-54.

Megías, A., Navas, J. F., Perandrés-Gómez, A., Maldonado, A., Catena, A., \& Perales, J. C. (2018). Electroencephalographic evidence of abnormal anticipatory uncertainty processing in gambling disorder patients. Journal of Gambling Studies, 34, 321-338.

Mendoza, Y., Cuello, P., \& López, V. (2016). Análisis psicométrico del inventario de sintomatología prefrontal (ISP) en sujetos adictos y no adictos [Psychometric analysis Inventory Prefrontal Symptoms addicted and non-addicted subjetcs]. Revista Chilena de Neuropsicología, 11, 24-29.

Navas, J. F., Torres, A., Cándido, A., \& Perales, J. C. (2014). ¿'Nada' o 'un poco'? ¿'Mucho' o 'demasiado'? La impulsividad como marcador de gravedad en niveles problemático y no problemático de uso de alcohol e Internet ['Nothing' or 'just a bit'? 'Much' or 'too much'? Impulsivity traits as markers of severity transitions within non-problematic and problematic ranges of alcohol and Internet use]. Adicciones, 26, 146-158.

Navas, J. F., Verdejo-Garcia, A., Lopez-Gomez, M., Maldonado, A., \& Perales, J. C. (2016). Gambling with rose-tinted glasses on: Use of emotion-regulation strategies correlates with dysfunctional cognitions in gambling disorder patients. Journal of Behavioral Addictions, 5, 271-281.

Panova, T., \& Carbonell, X. (2018). Is smartphone addiction really an addiction? Journal of Behavioral Addictions, 7, 252-259.

Pedrero-Pérez, E. J. (2010). Detección de adicciones comportamentales en adictos a sustancias en tratamiento [Screening of behavioral addictions in substance-addicted patients]. Trastornos Adictivos, 12, 13-18

Pedrero-Pérez, E. J., Morales-Alonso, S., Gallardo-Arriero, V., Blázquez-Rollón, L. FolgueraExpósito, I., \& Ruiz-Sánchez de León, J. M. (2020). The UPPS model of impulsivity in the 
abuse of Information and Communication Technologies (ICT). Adicciones. Advance online publication. doi: 10.20882/adicciones.1449

Pedrero-Pérez, E. J., Morales-Alonso, S., \& Ruiz-Sánchez de León, J. M. (2021). Obsession and compulsion in mobile phone use/abuse: OCDUS-ICT. Adicciones, 33(2), 149-160.

Pedrero-Pérez, E. J., Rodríguez-Monje, M. T., Gallardo-Alonso, F., Fernández-Girón, M., PérezLópez, M., \& Chicharro-Romero, J. (2007). Validación de un instrumento para la detección de trastornos de control de impulsos y adicciones: El MULTICAGE CAD-4 [Validation of a tool for screening of impulse control disorders and addiction: MULTICAGE CAD-4]. Trastornos Adictivos, 9, 269-278.

Pedrero-Pérez, E. J., Ruiz-Sánchez de León, J. M., Morales-Alonso, S., Pedrero-Aguilar, J., \& Fernández-Méndez, L. M. (2015). Sintomatología prefrontal en la vida diaria: Evaluación de cribado mediante el Inventario de síntomas prefrontales abreviado (ISP-20) [Prefrontal clinical symptoms in daily living: Screening assessment by means of the short Prefrontal Symptoms Inventory (PSI-20)]. Revista de Neurología, 60, 385-393.

Pedrero-Pérez, E. J., Ruiz-Sánchez de León, J. M., Rojo-Mota, G., Llanero-Luque, M., PedreroAguilar, J., Morales-Alonso, S., \& Puerta-García, C. (2018). Tecnologías de la información y la comunicación (TIC): Uso problemático de Internet, videojuegos, teléfonos móviles, mensajería instantánea y redes sociales mediante el MULTICAGE-TIC [Information and Communications Technologies (ICT): Problematic use of Internet, video games, mobile phones, instant messaging and social networks using MULTICAGE-TIC]. Adicciones, 30, 19-32.

Pedrero-Pérez, E. J., Ruiz Sánchez de León, J. M., Rojo Mota, G., Morales Alonso, S., Pedrero Aguilar, J., Lorenzo Luque, I., \& González Sánchez, Á. (2016). Inventario de síntomas prefrontales (ISP): Validez ecológica y convergencia con medidas neuropsicológicas [Prefrontal Symptoms Inventory (PSI): Ecological validity and convergence with neuropsychological measures]. Revista de Neurología, 63, 241-251.

Quiroga, M. A., Herranz, M., Gómez-Abad, M., Kebir, M., Ruiz, J., \& Colom, R. (2009). Videogames: Do they require general intelligence? Computers \& Education, 53(2), 414-418.

Quiroga, M. Á., Román, F. J., de la Fuente, J., Privado, J., \& Colom, R. (2016). The Measurement of Intelligence in the XXI Century using Video Games. Spanish Journal of Psychology, 19(e89), 1-13.

Reneses, B., Garrido, S., Navalón, A., Martín, O., Ramos, I., Fuentes, M., Moreno, J., \& LópezIbor, J. J. (2015). Psychiatric morbidity and predisposing factors in a primary care population in Madrid. International Journal of Social Psychiatry, 61, 275-286.

Robbins, T. W., \& Clark, L. (2015). Behavioral addictions. Current Opinion in Neurobiology, $30,66-72$

Rodríguez-Monje, M. T., Pedrero-Pérez, E. J., Fernández-Girón, M., Gallardo-Alonso, F., \& Sanz-Cuesta, T. (2009). Detección precoz de conductas adictivas en atención primaria: utilización del MULTICAGE CAD-4 [Early detection of addictive behaviour in primary health care. Use of MULTICAGE CAD-4]. Atención Primaria, 41, 25-32.

Rodriguez-Monje, M. T., Pedrero-Perez, E. J., Rodriguez-Alonso, E., Fernandez-Girón, M., Pastor-Ramos, V., Mateo-Madurga, A., del Cura-González, I., Sanz-Cuesta, T., AranaCañedo, C., Sánchez-Salgado, M. P., \& Escriva-Ferrairo, R. A. (2019). MULTICAGE CAD4 for behavioral addiction screening: Structural validity after inclusion of a scale on smartphone abuse. Anales de Psicología, 35, 41-46.

Ruiz-Sánchez de León, J. M., Pedrero-Pérez, E. J., Gálvez, S., Fernández-Méndez, L. M., \& Lozoya-Delgado, P. (2015). Utilidad clínica y propiedades psicométricas del inventario de síntomas prefrontales (ISP) en el daño cerebral adquirido y las demencias degenerativas [Clinical utility and psychometric properties of Prefrontal Symptoms Inventory (PSI) in acquired brain injury and degenerative dementias]. Revista de Neurología, 61, 387-394. 
Siciliano, C. A., Noamany, H., Chang, C. J., Brown, A. R., Chen, X., Leible, D., Lee, J. J., Wang, J., Vernon, A. N., Vander Weele, C., Kimchi, E. Y., Heiman, M., \& Tye, K. M. (2019). A cortical-brainstem circuit predicts and governs compulsive alcohol drinking. Science, 366(6468), 1008-1012.

Tiego, J., Oostermeijer, S., Prochazkova, L., Parkes, L., Dawson, A., Youssef, G., Oldenhof, E., Carter, A., Segrave, R. A., Fontenelle, L. F., \& Yücel, M. (2019). Overlapping dimensional phenotypes of impulsivity and compulsivity explain co-occurrence of addictive and related behaviors. CNS Spectrums, 24, 426-440.

Yücel, M., Oldenhof, E., Ahmed, S. H., Belin, D., Billieux, J., Bowden-Jones, H., Carter, A., Chamberlain, S. R., Clark, L., Connor, J., Daglish, M., Dom, G., Dannon, P., Duka, T., Fernández-Serrano, M. J., Field, M., Franken, I., Goldstein, R., Gonzalez, R.,... VerdejoGarcía, A. (2019). A transdiagnostic dimensional approach towards a neuropsychological assessment for addiction: an international Delphi consensus study. Addiction, 114, 1095-1109.

RECEIVED: June 13,2020

ACCEPTED: February 23, 2021 